\title{
Effect of hydroponic and peat-free media in transplant production of Rudbeckia hirta varieties under different photoperiodic lighting and their photosynthetic parameters
}

\author{
Antal, G. ${ }^{1}$, Kurucz, E. ${ }^{1}$, Koncz, K. ${ }^{1}$, Kaszás, L. ${ }^{2}$ \& Fári, M. G. ${ }^{2}$ \\ ${ }^{1}$ University of Debrecen, Faculty of the Agricultural and Food Sciences and Environment Management, Institute of Horticulture, \\ 138. Böszörményi str., Debrecen, H-4032, Hungary \\ ${ }^{2}$ University of Debrecen, Faculty of the Agricultural and Food Sciences and Environment Management, \\ Department of Applied Plant Biology, 138. Böszörményi str., Debrecen, H-4032, Hungary \\ Author for correspondence: antal.gabriella@agr.unideb.hu
}

\begin{abstract}
Summary: The purpose of this research was to determine the effects of varieties, different light conditions (short day, long day, natural short day with light pollution), and different growing media (perlite, peat-free, peat-based, aeroponics system) on Rudbeckia hirta plant production under controlled conditions (greenhouse). The morphological effects of each treatment (photoperiodic lightings and media) on different Rudbeckia varieties determined at 11 weeks-old 'Napfény', 'Toto Gold', 'Autumn Colors', 'Prairie Sun' and 16 weeks-old 'Napfény'. Plantlets received 12 hours daylight did not initiate flowers, remained stage of the leaf rosette in case of all varieties. The 14 hours light treatment in the aeroponics system and the same treatment in perlite and control (natural short day with 14 hours light pollution) plantlets had developed inflorescences or flower buds. The inflorescence axis of 'Napfény' was appeared at 13 weeks under long-day conditions, with 1.7 (perlite) - 2.7 (aeroponics) flower buds in 16 weeks. 'Toto Gold', 'Autumn Colors', 'Prairie Sun' varieties developed inflorescences at 8 weeks, 14 hours aeroponics system resulted in the most of flower buds ('Toto Gold': 6.5, 'Autumn Colors': 3.25, 'Prairie Sun': 4.8 flower buds) at 11 weeks. Long daylight manipulation could be minimized crop times and achieved flowering potted plants at 11 weeks. The peat-based and peat-free media effect was observed on 'Autumn Colors'. The number of leaves of peat-free 'Autumn Colors' transplants (16.8-20.3) was significantly higher than peat-based media (13.5-15.5). Other morphological parameters were not affected by the media treatments.
\end{abstract}

Antal, G., Kurucz, E., Koncz, K., Kaszás, L., Fári, M. G. (2021): Effect of hydroponic and peat-free media in transplant production of Rudbeckia hirta varieties under different photoperiodic lighting and their photosynthetic parameters. International Journal of Horticultural Science 27: 110-117. https://doi.org/10.31421/ijhs/27/2021/9865

Key words: Rudbeckia hirta, photoperiodic lighting treatment, peat-free media, aeroponics system, seedlings cultivation, photosynthetic pigment content

\section{Introduction}

The genus Rudbeckia consists approximately 30 annuals, biennial and perennial species, and it belongs to Asteraceae family (Palmer et al., 2009). Rudbeckia hirta L. (black-eyed Susan) is a native species in North America, it has been known as an annual ornamental plant (flowerbed, pot/container plants, cut flower). Rudbeckia hirta contains numerous flavonoid-, anthocyanin compounds, phenolic acids, etc. (Luczkiewcz \& Cisowski, 2001; Hambäck, 2001; Michael, et al., 2014), traditionally it has been utilized as medicinal plant (e.g. colds, earache, sores or snakebites etc.) (Harkess \& Lyons, 2019; Brakie, 2019). Rudbeckia species as long day plants are required for flower initiation more than 13 hours lighting per day. Numerous Rudbeckia species and varieties have been reported in experiments of photoperiodic and flowering treatments: $R$. bicolor var. superba and $R$. speciosa (Murneek, 1940), Rudbeckia fulgida 'Goldsturm' (Runkle et al., 1999; Elkins \& van Iersel, 2020) and Rudbeckia hirta (Beckwith, 1991; Blanchard \& Runkle, 2010; Werner et al., 2011).

Photosynthetic light inside a greenhouse or controlled environments can be a limiting factor, electric lamps (e.g. highpressure sodium - HPS fixtures or light-emitting diodes LEDs) are provided supplemental lighting in the horticultural production. The efficacy of HPS or LEDs lighting ( $\mu \mathrm{mol} / \mathrm{J}$ ) has increased intensely in the past decades resulted that indoor or light controlled plant production have recently become more economically viable (Kozai, 2016; Roberto \& Runkle, 2017).

Ornamental cultivation basically depends on the quality of growing media. Peat-based media have been dominated in pot/bedding plants and nursery production of plants. Increased mining and utilization of peat, have been destroyed habitats and potentially contributed to climate change. Among of other countries, the UK government and European Union have increasingly encouraged to reduce peat uses for industrial and horticultural purposes (FAI, 2014; IUCN, 2018; European Commission, 2018; Bek et al., 2020).

One of the alternatives, hydroponic cultivation of plants has been a well-known and widespread technology also in ornamental plant cultivation (especially cut flowers, foliage and flowering production) (Sardare \& Shraddha, 2013; Roberto \& Runkle, 2017). There are a few online available literatures of hydroponic cultivation of Rudbeckia hirta, and primarily are focused on the effect of different nutrients to detection of secondary compounds (Almeida-Cortez et al., 2003). 
The objectives of present paper are to characterize nursery production of different Rudbeckia hirta varieties depending on photoperiodic lighting treatments (short day, long day, natural short day with light pollution) and growing media (perlite, peat-free, peat-based, aeroponics system) considering morphological characterization and photosynthetic parameters.

\section{Materials and methods}

Germinations and pot experiments were conducted at University of Debrecen, Faculty of the Agricultural and Food Sciences and Environment Management, in Biological Research and Plant Experiment Greenhouse (Biodrome) from November 2020 to April 2021 (Hungary), during natural shortday conditions. The computer controlled air-temperature (Priva Climate Computer) was at least $20.5{ }^{\circ} \mathrm{C}$ at daytimes and at least $16{ }^{\circ} \mathrm{C}$ at nights during our experiment.

\section{Plant material}

Four Rudbeckia hirta varieties were investigated: 'Napfény' variety was provided by National Agricultural Research and Innovation Centre (NARIC, Hungary), 'Autumn Colors', 'Prairie Sun', 'Toto Gold' were derived by Jelitto Staudensamen GmbH (Germany) (Benary, 2013, 2020; NARIC, 2020a,b).

\section{Germination, nursery methods and media}

Rudbeckia hirta seeds were surface sterilized in $100 \mathrm{ml}$ Erlenmeyer flasks with $10 \%$ SteriClean Plant disinfectant (Pannon Trade Kft., Hungary) for 15 minutes and were rinsed with reverse osmosis (RO) water (tap water was cleaned by Power Grow 500 - Reverse Osmosis System, Growmax Water, USA) at three times. The surface sterilized seeds were sown in Petri-dish (10 cm diameter, polystyrene, VWR International Ltd., Hungary), into white filter paper (VWR International Ltd., Hungary) and were soaked with $5 \mathrm{ml}$ RO water. Petridishes were placed on a heat mat (Root!iT Heat Mat, Playgrowned.com, Hungary) with thermostat, to ensure constant temperature of $22{ }^{\circ} \mathrm{C}$ for germination. $5 \mathrm{ml}$ of $\mathrm{RO}$ water was poured onto the filter paper at two times during germination stage. The seeds were germinated under 12 hours supplemental light (HortiLED Multi 4DIM, Hortilux, Netherlands) with light intensity of $150 \mu \mathrm{mol} \mathrm{m} \mathrm{m}^{-2} \mathrm{~s}^{-1}$ PPFD (photosynthetic photon flux density).

Rudbeckia seeds were sowed on $26^{\text {th }}$ November, 2020 ('Napfény') and $4^{\text {th }}$ January, 2021 ('Autumn Colors', 'Toto Gold' and 'Prairie Sun') for nursery treatments. 3 weeks of well-developed seedlings were transferred to Rockwool cubes (25x25x40 mm, Grodan, Playgrowned.com, Hungary) for soilfree, hydroponic (aeroponics system, perlite) and different photoperiodic lighting experiments. 'Napfény' and 'Autumn Colors' were sowed on $16^{\text {th }}$ January, 2021 and 3 weeks of welldeveloped seedlings were transferred to Jiffy-7 pellet (Playgrowned.com, Hungary) for the peat-based, peat-free media and different photoperiodic lighting experiments. The seedlings were grown under 12 hours light treatment by HortiLED with light intensity of $150 \mu \mathrm{mol} \mathrm{m} \mathrm{m}^{-2} \mathrm{~s}^{-1}$ PPFD for 3 weeks.

Terra Aquatica Tripart advanced nutrient solutions (Micro, Grow and Bloom 3-Part Flora Series, General Hydroponics Europe - GHE) were utilized with RO water, according to the user guide of products and development phases of seedlings (GHE, 2021). $0.5 \mathrm{ml} /$ litre concentrates from each nutrient solution (Terra Aquatica, Tripart, GHE) were irrigated the seedlings every week ( $25 \mathrm{ml} /$ seedlings/ week) until 3 leaves and well-developed roots were appeared. 'Napfény', 'Autumn Colors', 'Toto Gold', 'Prairie Sun' varieties were grown in Rockwool cubes planted into aeroponics system (GHE Rainforest 72, Playgrowned.com, Hungary), and into $9 \mathrm{~cm}$ diameter plastic pots (Gazdabolt.hu, Hungary) with horticultural perlite (particle size: 2-6 mm, Magyar Perlit Kft., Hungary). 'Napfény' and 'Autumn Colors' varieties were grown in Jiffy pellet, planted into $9 \mathrm{~cm}$ diameter plastic pots (Gazdabolt.hu, Hungary) with peat based soil mixture (JÓFÖLD for plantlets, Pax96 Kft., Hungary) and peat-free soil mixture (OBI, Living Garden, for plantlets, Hungary).

\section{Photoperiodic lighting treatments}

LED light treatment (HortiLED Multi 4DIM, Hortilux, Netherlands) was utilized to the following photoperiodic parameters. Each variety with growing media of perlite, peatbased and peat-free soil mixture was grown under 12 hours, 14 hours artificial light conditions and natural short day with 14 hours light pollution (PPFD below $1 \mu \mathrm{mol} \mathrm{m} \mathrm{m}^{-2} \mathrm{~s}^{-1}$ and 15 lux after sunset). Light intensity of short-day (12 hours) and longday (14 hours) light treatments were $210 \mu \mathrm{mol} \mathrm{m} \mathrm{m}^{-2} \mathrm{~s}^{-1}$ PPFD. Rudbeckia varieties in GHE aeroponics system were grown only under 14 hours artificial LED light.

\section{Measurement of morphological parameters of plantlet cultivation}

The following morphological properties were determined in the 11 weeks-old seedlings: number of leaves, number of shoots, plant height $(\mathrm{cm})$, number of flower buds in each variety, depending on photoperiodic lighting treatment (short day, long day, natural short day with light pollution) and different growing media (perlite, peat-free, peat-based, aeroponics system). At least 5 plantlets of 'Toto Gold', 'Autumn Colors', 'Prairies Sun' and 'Napfény' varieties were measured. Napfény’ variety was grown more slowly than others in our experiments of winter-early spring conditions, so were also evaluated by the end of 16-weeks-old 'Napfény' plantlet in case of soilless and aeroponics experiment. Time of appearance of flower buds and reducible time of plantlet cultivation (weeks) of varieties determined depending on growing media and light treatments.

\section{Photosynthetic pigment and relative chlorophyll content (SPAD value) determination}

Relative chlorophyll content (SPAD value) of the leaves was measured with a Minolta SPAD-502 meter. SPAD values were determined from 6 average measurements (derived from a minimum of 3 measured data) in each variety depending on the treatments.

Photosynthetic pigment content and ratio were determined based on Duma et al. (2014) methods with spectrophotometer (Ultraspec 2100 pro, Biochrom) at 665, 649, 495, 480, $440 \mathrm{~nm}$. 2-3 well-developed leaves were measured and collected from upper part of the shoots (a third or fourth leaves from shoot tips) at the end of 11 weeks after sowing of each variety (and as well as 16-weeks-old 'Napfény' variety). Samples were lyophilized by Christ Alfa 1-4 LSC lyophilizer for 
determination of different photosynthetic pigment content (mg/g). Chlorophyll $a$ (chl $a$ ), chlorophyll $b$ (chl b), carotinoids (car), xanthophyll (lutein) and SPAD-value were calculated in each variety depending on the treatments.

\section{Data analyses}

Descriptive statistical methods, including the mean, standard deviation and one-way and two-way ANOVA were used. The results were evaluated with Microsoft Office Excel and SPSS 22.0 (SPSS Inc., Chicago, IL) programmes. The significant differences between the variants were determined with Tukey's (if equal variances assumed) test at a probability level of $5 \%$.

\section{Results}

\section{Morphological parameters of aeroponics and soilless Rudbeckia plantlet cultivation with photoperiodic lighting treatments}

The morphological effects of each treatment (photoperiodic lightings and media) on different Rudbeckia varieties ('Napfény', 'Toto Gold', 'Autumn Colors', 'Prairies Sun') were shown in Figure 1-4. 11 weeks-old 'Toto Gold', 'Autumn Colors' and 'Prairies Sun' were already suitable for acclimatization or planting, furthermore due to slower growing of 'Napfény', 11 and 16 weeks-old 'Napfény' plantlets were also shown in results.

Plantlets were received 12 hours day light did not initiate flowers, remained stage of the leaf rosette without exception. In case of 14 hours aeroponics, 14 hours perlite and control (natural short day with 14 hours light pollution) plantlets were developed inflorescences or flower buds (Figure 1-4.). Inflorescence axis of 'Napfény' was appeared at 13 weeks also in light polluted control plantlets, in perlite was 1.7 and in aeroponics 2.7 flower buds were developed at 16 weeks in long day treatments (Figure 1.). Other varieties (Figure 2-4.) were developed inflorescences at 8 weeks, 14 hours aeroponics system resulted the most of flower buds: 'Toto Gold' was 6.5 (Figure 2.), 'Autumn Colors' was 3.25 (Figure 3.), 'Prairie Sun' was 4.8 (Figure 4.) flower buds in 11 weeks. Long daylight manipulation could be minimized crop times and achieved flowering potted plants at 11 weeks.

Lengths of plantlets under 12 hours of light treatment were significantly smaller than long day supplemental lightings and light polluted control. Under long day, varieties were shown natural height characteristics. In aeroponics systems (GHE Rainforest72) with 14 hours supplementary lighting, plantlets were the highest, because of the appearance of inflorescences. Taller varieties with higher habitat, 'Napfény' and 'Prairie Sun' produced 30.2 and $36.8 \mathrm{~cm}$ high plantlets, compact and well branched 'Toto Gold' was $22 \mathrm{~cm}$, medium tall 'Autumn Colors' was $27 \mathrm{~cm}$ height in aeroponics system. There were not significant differences $(\mathrm{p}=0.05)$ between aeroponics and perlite media, except for 'Toto Gold' (Table 1).

Number of leaves of each variety responded differently. There were not significant differences $(p=0.05)$ between perlite media depending on light treatments, except for 14 hours aeroponics treatment of 'Prairie Sun' (42.4). Most of leaves developed in aeroponics cultivation system, 'Toto Gold' was the highest (45.3), due to the branching growth of the variety (Table 2).

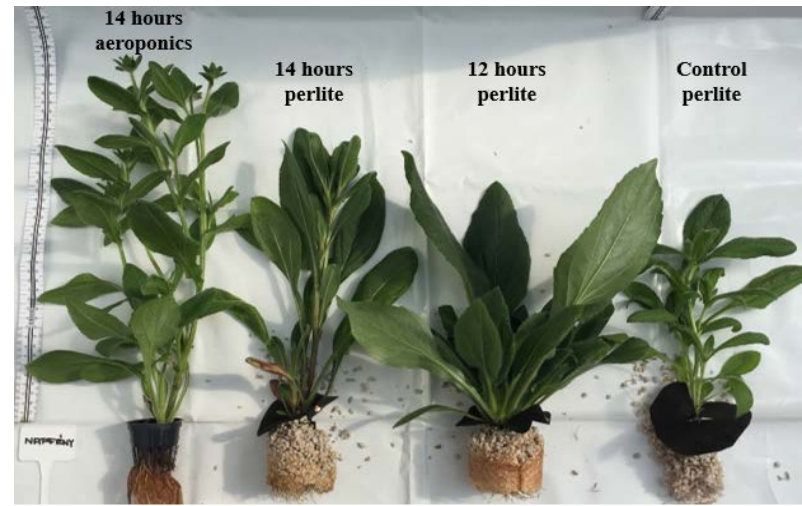

Figure 1. 16 weeks-old Rudbeckia hirta 'Napfény' plantlets depending on photoperiodic lighting treatments and media (University of Debrecen, Biological Research and Plant Experiment Greenhouse - Biodrome, Debrecen, Hungary, 2021) .

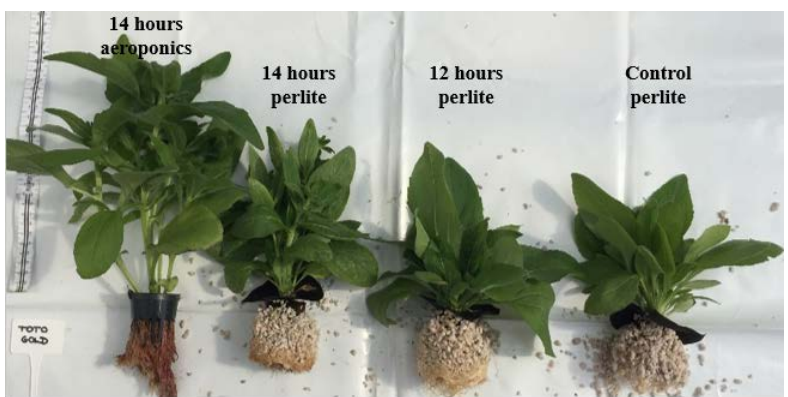

Figure 2. 11 weeks-old Rudbeckia hirta 'Toto Gold' plantlets depending on photoperiodic lighting treatments and media (University of Debrecen, Biological Research and Plant Experiment Greenhouse - Biodrome, Debrecen, Hungary, 2021).

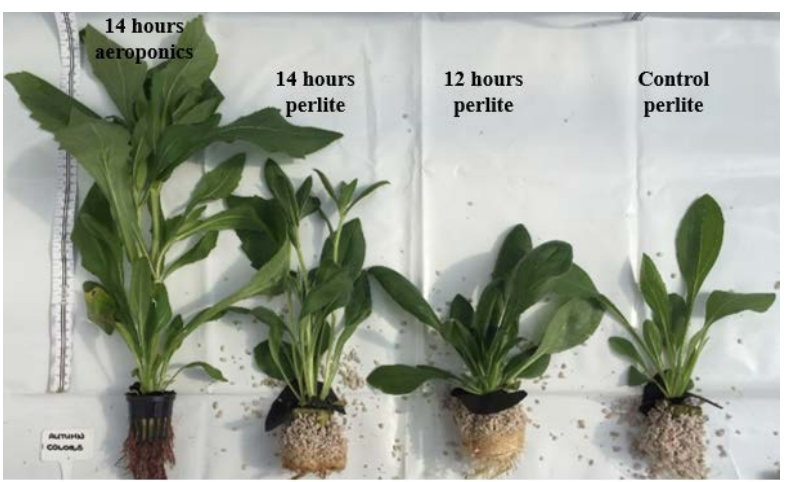

Figure 3. 11 weeks-old Rudbeckia hirta 'Autumn Colors' plantlets depending on photoperiodic lighting treatments and media (University of Debrecen, Biological Research and Plant Experiment Greenhouse - Biodrome, Debrecen, Hungary, 2021).

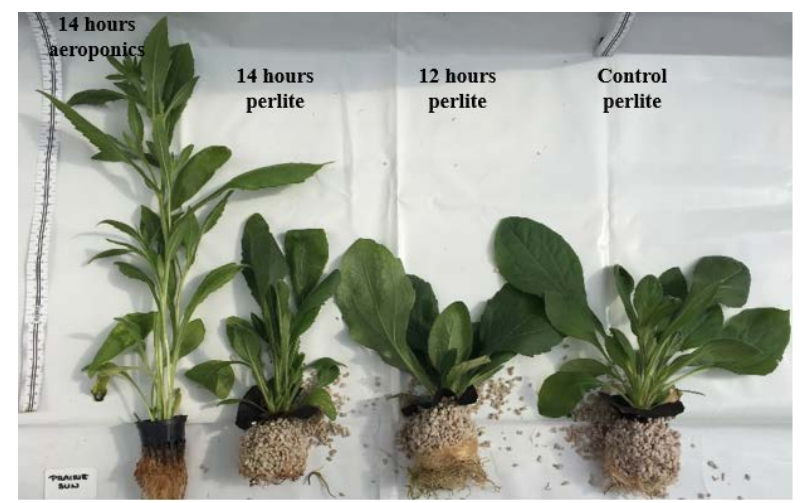

Figure 4. 11 weeks-old Rudbeckia hirta 'Prairie Sun' plantlets depending on photoperiodic lighting treatments and media (University of Debrecen, Biological Research and Plant Experiment Greenhouse - Biodrome, Debrecen, Hungary, 2021). 
Table 1. Lengths of 11 and 16 weeks Rudbeckia hirta L. plantlets depending on photoperiodic lighting treatments and media (University of Debrecen, Biological Research and Plant Experiment Greenhouse - Biodrome, Debrecen, Hungary, 2021).

\begin{tabular}{|c|c|c|c|c|}
\hline & $\begin{array}{l}14 \text { hours - } \\
\text { aeroponics }\end{array}$ & $\begin{array}{l}14 \text { hours - } \\
\text { perlite }\end{array}$ & $\begin{array}{l}12 \text { hours - } \\
\text { perlite }\end{array}$ & $\begin{array}{c}\text { Control - } \\
\text { perlite }\end{array}$ \\
\hline $\begin{array}{c}\text { 'Napfény' } \\
\text { (11 weeks) } \\
\pm S D\end{array}$ & $\begin{array}{l}8.1 a \\
\pm 5.61\end{array}$ & $\begin{array}{l}9.3 a \\
\pm 3.60\end{array}$ & $\begin{array}{l}9.0 a \\
\pm 3.61\end{array}$ & $\begin{array}{r}7.7 a \\
\pm 1.21\end{array}$ \\
\hline $\begin{array}{c}\text { 'Napfény' } \\
\text { (16 weeks) } \\
\pm S D \\
\end{array}$ & $\begin{array}{l}30.2 b \\
\pm 3.11 \\
\end{array}$ & $\begin{array}{r}25.2 a b \\
\pm 13.75 \\
\end{array}$ & $\begin{array}{r}14.3 a \\
\pm 1.53 \\
\end{array}$ & $\begin{array}{c}22.0 a b \\
\pm 2.00 \\
\end{array}$ \\
\hline $\begin{array}{c}\text { 'Toto Gold' } \\
\text { (11 weeks) } \\
\pm S D \\
\end{array}$ & $\begin{array}{l}22.0 C \\
\pm 3.46\end{array}$ & $\begin{array}{r}14.7 b \\
\pm 2.30 \\
\end{array}$ & $\begin{array}{r}8.3 a \\
\pm 1.52 \\
\end{array}$ & $\begin{array}{c}12.0 a b \\
\pm 1.73\end{array}$ \\
\hline $\begin{array}{c}\text { 'Autumn } \\
\text { Colors' } \\
\text { (11 weeks) } \\
\pm S D\end{array}$ & $\begin{array}{l}27.0 b \\
\pm 6.78\end{array}$ & $\begin{array}{l}24.0 b \\
\pm 7.55\end{array}$ & $\begin{array}{l}10.3 a \\
\pm 2.52\end{array}$ & $\begin{array}{l}11.0 a b \\
\pm 2.65\end{array}$ \\
\hline $\begin{array}{c}\text { 'Prairie Sun' } \\
\text { (11 weeks) } \\
\pm S D\end{array}$ & $\begin{array}{r}36.8 b \\
\pm 6.30 \\
\end{array}$ & $\begin{array}{r}21.0 a b \\
\pm 7.00\end{array}$ & $\begin{array}{r}9.3 a \\
\pm 1.53 \\
\end{array}$ & $\begin{array}{c}14.7 a b \\
\pm 0.58 \\
\end{array}$ \\
\hline
\end{tabular}

Note: Values followed by the different letters represent significant differences depending on treatments, which were determined with Tukey's test ( $p=0.05)$.

Table 2. Number of leaves of 11 and 16 weeks Rudbeckia hirta L. plantlets depending on photoperiodic lighting treatments and media (University of Debrecen, Biological Research and Plant Experiment Greenhouse - Biodrome, Debrecen, Hungary, 2021).

\begin{tabular}{|c|c|c|c|c|}
\hline & $\begin{array}{c}\mathbf{1 4} \text { hours - } \\
\text { aeroponics }\end{array}$ & $\begin{array}{c}\mathbf{1 4} \text { hours - } \\
\text { perlite }\end{array}$ & $\begin{array}{c}\mathbf{1 2} \text { hours - } \\
\text { perlite }\end{array}$ & $\begin{array}{c}\text { Control - } \\
\text { perlite }\end{array}$ \\
\hline $\begin{array}{c}\text { 'Napfény' } \\
(11 \text { weeks) } \\
\pm S D\end{array}$ & $\mathbf{8 . 2} a$ & $\mathbf{6 . 5} a$ & $\mathbf{6 . 3} a$ & $\mathbf{6 . 3} a$ \\
\pm 4.52 & \pm 1.38 & \pm 1.15 & \pm 2.52 \\
\hline $\begin{array}{c}\text { 'Napfény' } \\
(16 \text { weeks) } \\
\pm S D\end{array}$ & $\mathbf{3 1 . 5} a$ & $\mathbf{2 6 . 8} a$ & $\mathbf{2 9 . 0} a$ & $\mathbf{2 8 . 7} a$ \\
\hline $\begin{array}{c}\text { 'Toto Gold' } \\
\text { (11 weeks) } \\
\pm S D\end{array}$ & $\mathbf{4 5 . 3} a$ & $\mathbf{4 2 . 7} a$ & $\mathbf{3 2 . 7} a$ & $\mathbf{3 9 . 0} a$ \\
\hline $\begin{array}{c}\text { 'Autumn } \\
\text { Colors' }\end{array}$ & $\mathbf{3 3 . 3} a$ & $\mathbf{1 9 . 8} a$ & $\mathbf{2 4 . 3} a$ & $\mathbf{1 5 . 3} a$ \\
$\begin{array}{c}\text { (11 weeks) } \\
\pm S D\end{array}$ & \pm 7.57 & \pm 13.96 & \pm 8.96 & \pm 2.52 \\
\hline $\begin{array}{c}\text { 'Prairie Sun' } \\
(11 \text { weeks) } \\
\pm S D\end{array}$ & $\mathbf{4 2 . 4} b$ & $\mathbf{1 9 . 7} a$ & $\mathbf{2 0 . 7} a$ & $\mathbf{1 9 . 0} a$ \\
\pm 8.38 & \pm 2.52 & \pm 6.66 & \pm 6.00 \\
\hline
\end{tabular}

Note: Values followed by the same letter are not significantly different depending on treatments according to Tukey's test ( $p=0.05)$.

Table 3. Number of shoots of 11 and 16 weeks Rudbeckia hirta L. plantlets depending on photoperiodic lighting treatments and media (University of Debrecen, Biological Research and Plant Experiment Greenhouse - Biodrome, Debrecen, Hungary, 2021).

\begin{tabular}{|c|c|c|c|c|}
\hline & $\begin{array}{l}14 \text { hours - } \\
\text { aeroponics }\end{array}$ & $\begin{array}{l}14 \text { hours - } \\
\text { perlite }\end{array}$ & $\begin{array}{l}12 \text { hours - } \\
\text { perlite }\end{array}$ & $\begin{array}{l}\text { Control - } \\
\text { perlite }\end{array}$ \\
\hline $\begin{array}{c}\text { 'Napfény' } \\
\text { (11 weeks) } \\
\pm S D \\
\end{array}$ & $\begin{array}{r}1.6 a \\
\pm 0.97 \\
\end{array}$ & $\begin{array}{r}1.0 a \\
\pm 0.00 \\
\end{array}$ & $\begin{array}{r}1.0 a \\
\pm 0.00 \\
\end{array}$ & $\begin{array}{r}1.0 a \\
\pm 0.00 \\
\end{array}$ \\
\hline $\begin{array}{c}\text { 'Napfény' } \\
\text { (16 weeks) } \\
\pm S D\end{array}$ & $\begin{array}{l}1.6 a \\
\pm 0.79 \\
\end{array}$ & $\begin{array}{l}3.2 a b \\
\pm 1.79 \\
\end{array}$ & $\begin{array}{r}4.0 b \\
\pm 1.00 \\
\end{array}$ & $\begin{array}{l}3.6 a b \\
\pm 2.00 \\
\end{array}$ \\
\hline $\begin{array}{c}\text { 'Toto Gold' } \\
\text { (11 weeks) } \\
\pm S D \\
\end{array}$ & $\begin{array}{r}4.0 a \\
\pm 0.82 \\
\end{array}$ & $\begin{array}{l}5.7 a b \\
\pm 0.58 \\
\end{array}$ & $\begin{array}{r}7.3 b \\
\pm 0.58 \\
\end{array}$ & $\begin{array}{r}6.0 b \\
\pm 1.00 \\
\end{array}$ \\
\hline $\begin{array}{c}\text { 'Autumn } \\
\text { Colors' } \\
\text { (11 weeks) } \\
\pm S D \\
\end{array}$ & $\begin{array}{r}2.8 a \\
\pm 0.95 \\
\end{array}$ & $\begin{array}{r}4.0 a \\
\pm 0.00 \\
\end{array}$ & $\begin{array}{r}4.0 a \\
\pm 1.00 \\
\end{array}$ & $\begin{array}{r}3.7 a \\
\pm 0.58 \\
\end{array}$ \\
\hline $\begin{array}{c}\text { 'Prairie Sun' } \\
\text { (11 weeks) } \\
\pm S D \\
\end{array}$ & $\begin{array}{r}4.2 a \\
\pm 1.92 \\
\end{array}$ & $\begin{array}{r}4.0 a \\
\pm 0.00 \\
\end{array}$ & $\begin{array}{r}4.7 a \\
\pm 0.58 \\
\end{array}$ & $\begin{array}{r}4.0 a \\
\pm 1.00 \\
\end{array}$ \\
\hline
\end{tabular}

Note: Values followed by the different letters represent significant differences depending on treatments, which were determined with Tukey's test $(p=0.05)$.
Figure 5. Lengths of 11 weeks-old Rudbeckia hirta L. varieties ('Napfény', 'Autumn Colors') depending on photoperiodic lighting treatments, peat-free and peat-based media (University of Debrecen, Biological Research and Plant Experiment Greenhouse - Biodrome, Debrecen, Hungary, 2021).

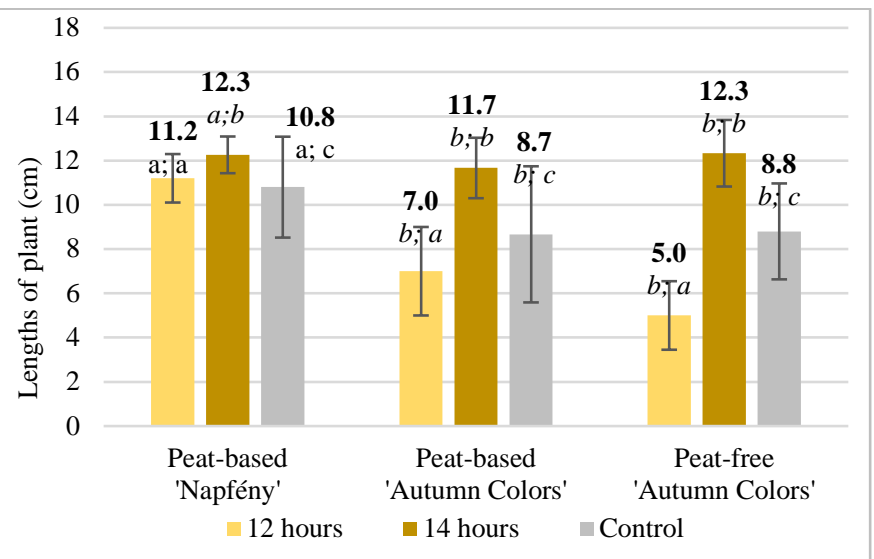

Notes: First different letters represent significant differences depending on media/varieties, second different letters represent significant differences depending on photoperiodic light treatments, which were determined with Tukey's test $(p=0.05)$. There is an interaction effect between lighting treatments and media ( $P$-value of lighting*media/varieties is 0.013$)$.

Figure 6. Number of leaves of 11 weeks-old Rudbeckia hirta L. varieties ('Napfény', 'Autumn Colors') depending on photoperiodic lighting treatments, peat-free and peat-based media (University of Debrecen, Biological Research and Plant Experiment Greenhouse - Biodrome, Debrecen, Hungary, 2021).

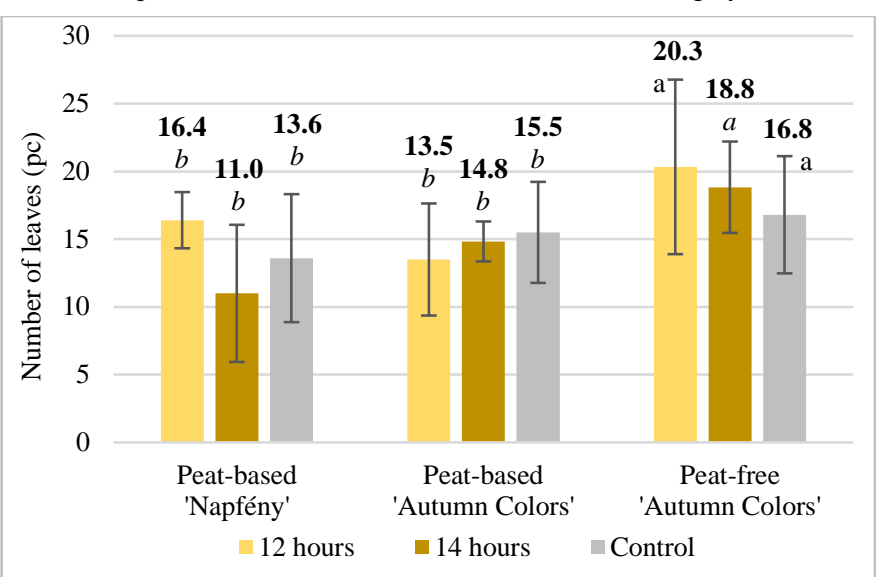

Notes: Different letters represent significant differences depending on media/varieties, which were determined with Tukey's test $(p=0.05)$. No significant differences between photoperiodic lighting treatments.

Figure 7. Number of shoots of 11 weeks-old Rudbeckia hirta L. varieties ('Napfény', 'Autumn Colors') depending on photoperiodic lighting treatments, peat-free and peat-based media (University of Debrecen, Biological Research and Plant Experiment Greenhouse - Biodrome, Debrecen, Hungary, 2021).

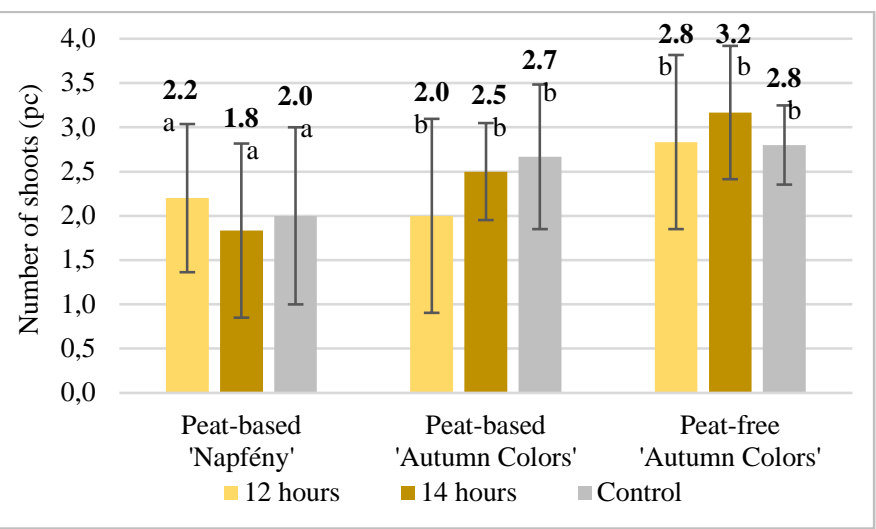

Notes: Different letters represent significant differences depending on media/varieties, which were determined with Tukey's test $(p=0.05)$. No significant differences between photoperiodic lighting treatments. 
Figure 8. 11 weeks-old Rudbeckia hirta 'Napfény' plantlets depending on photoperiodic lighting treatments in peat-based media (University of Debrecen, Biological Research and Plant Experiment Greenhouse - Biodrome, Debrecen, Hungary, 2021).

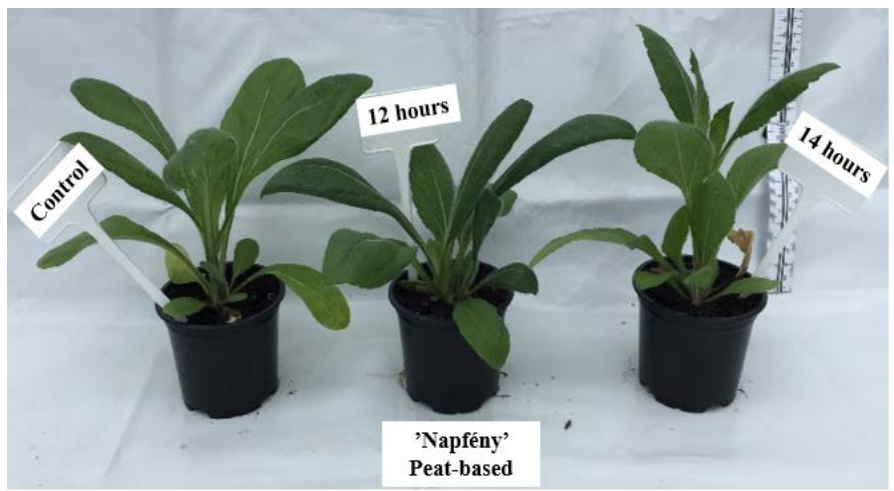

Figure 9. 11 weeks-old Rudbeckia hirta 'Autumn Colors' plantlets depending on photoperiodic lighting treatments in peat-based media (University of Debrecen, Biological Research and Plant Experiment Greenhouse - Biodrome, Debrecen, Hungary, 2021).

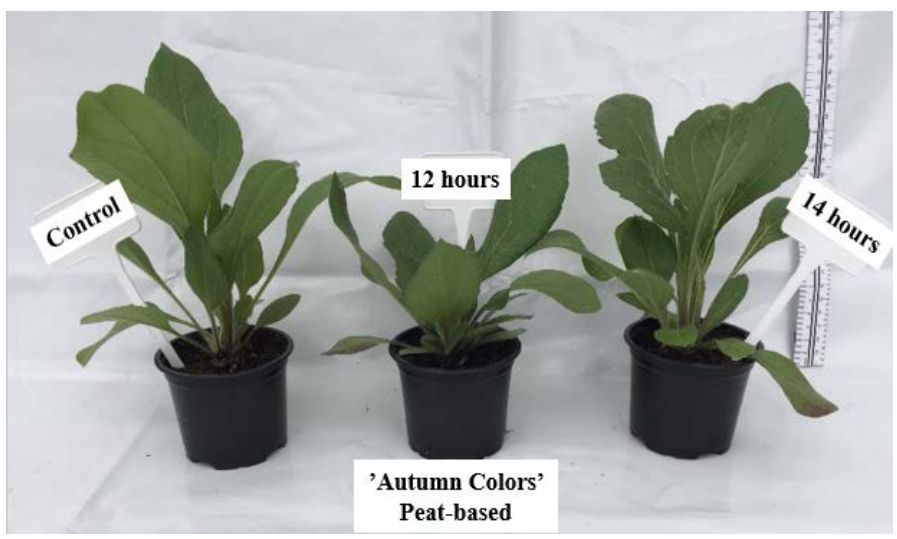

Figure 10. 11 weeks-old Rudbeckia hirta 'Autumn Colors' plantlets depending on photoperiodic lighting treatments in peat-free media (University of Debrecen, Biological Research and Plant Experiment Greenhouse - Biodrome, Debrecen, Hungary, 2021).

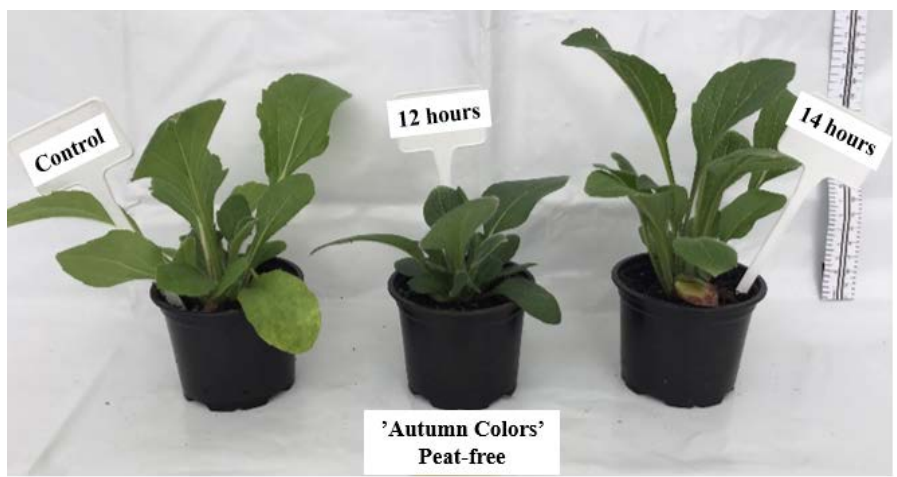

12 hours daylight resulted in vegetative growth of plantlets, most of the shoots developed in short-day treatment: 16 weeksold 'Napfény' and 11 weeks-old 'Autumn Colors' were developed 4 shoots under 12 hours. Because of natural short days in the winter-early spring season, varieties in control perlite media were developed fewer shoots than 12 hours.

11 weeks-old 'Toto Gold' was produced the most of the shoots (7.3), and the number of shoots of 'Prairie Sun' was 4.7 in 12 hours perlite treatments. In the aeroponics system with 14 hours of lighting, the number of shoots of 'Toto Gold' and 'Napfény' were 4.0 and 1.6, significantly less than 12 hours of lighting. In the case of 'Autumn Colors' and 'Prairies Sun were not significant differences $(\mathrm{p}=0.05)$ between treatments (Table 3).
Morphological parameters of peat-free and peat-based Rudbeckia plantlet cultivation with photoperiodic lighting treatments

Due to the similar habitats and longer crop times of 'Napfény' and 'Autumn Colors' were selected for peat-free and peat-based media and photoperiodic lighting experiments.

Peat-based 11 weeks-old 'Napfény' were significantly higher (11.2) than peat-based (7.0) or peat-free (5.0) 11 weeksold 'Autumn Colors' varieties. There were significant differences in plantlet length between each lighting treatment (12 hours, 14 hours, light-polluted control), so both media/varieties and lighting has affected height of plants. Length of control plantlets were between $8.7-10.8 \mathrm{~cm}$, plantlets treated 14-hours lightening were significantly higher than other treatments (11.7-12.3 cm) (Figure 5).

Number of leaves of peat-free 'Autumn Colors' plantlets were significantly higher than peat-based media/varieties. Depending on the daylight hours, it was between 16.8-20.3. Photoperiodic lighting treatments did not affect significantly the number of leaves none of the varieties. The peat-based 'Napfény' plantlets had least number of leaves (between 11.016.4) (Figure 6).

Number of shoots of peat-based and peat-free 'Autumn Colors' plantlets were significantly higher than peat-based 'Napfény'. There were not significant differences between peat-free and peat-based media of 'Autumn Colors' or photoperiodic lighting treatments (14 hours, 12 hours, light polluted control) in case of number of shoots. Most of the shoots were grown peat-free 'Autumn Colors' plantlets (between 2.8-3.2) depending on light conditions, the highest was 14-hour lighting (3.2 shoots). The lowest number of shoots (1.8) was observed in the 14 hours lighting peat-based 'Napfény' (Figure 7).

The morphological effects of control, 12 hours, 14 hours supplementary lightings and peat-free, peat based media on 'Napfény' and 'Autumn Colors' varieties were shown in Figure 8-10. Similar to aeroponics and perlite experiments, plantlets received 12 hours light treatment did not develop inflorescences or flower buds. 11 weeks-old 'Napfény' and 'Autumn Colors' varieties under 14 hours supplemental lighting and control were initiated inflorescence axis (Figure 8-10).

\section{Photosynthetic parameters of Rudbeckia varieties depending on different treatments}

Relative chlorophyll content (SPAD value) of Rudbeckia hirta L. varieties depending on photoperiodic lighting treatments and media were concluded in Table 4 and Figure 11.

'Napfény' plantlets treated with 12 hours light conditions were significantly higher relative chlorophyll content than other daylight (11 weeks-old was 35.3, 16 weeks-old was 46.8). SPAD values of Benary-bred varieties were the highest in 12 hours lightings (40.3-40.8), significantly higher than control plantlets in each variety. There were not significant differences between aeroponics and perlite media in 14 hours supplementary lighting in the case of either variety (Table 4).

Depending on media/varieties, did not significant differences between the SPAD value of peat-based 'Napfény' and peat-based 'Autumn Colors' (between 34.2-36.2 and between 34.5-40.0, consequently). SPAD values of peat-free 'Autumn Colors' were significantly higher (35.1-40.5) than peat-based 'Napfény'. Depending on the light treatment, SPAD 
values of 12 hours daylight plantlets (36.2-40.5), was significantly higher than others (Figure 11).

Figure 11. Relative chlorophyll content (SPAD value) of Rudbeckia hirta L. varieties ('Napfény', 'Autumn Colors') depending on photoperiodic lighting treatments, peat-free and peat-based media (University of Debrecen, Biological Research and Plant Experiment Greenhouse - Biodrome, Debrecen, Hungary, 2021).

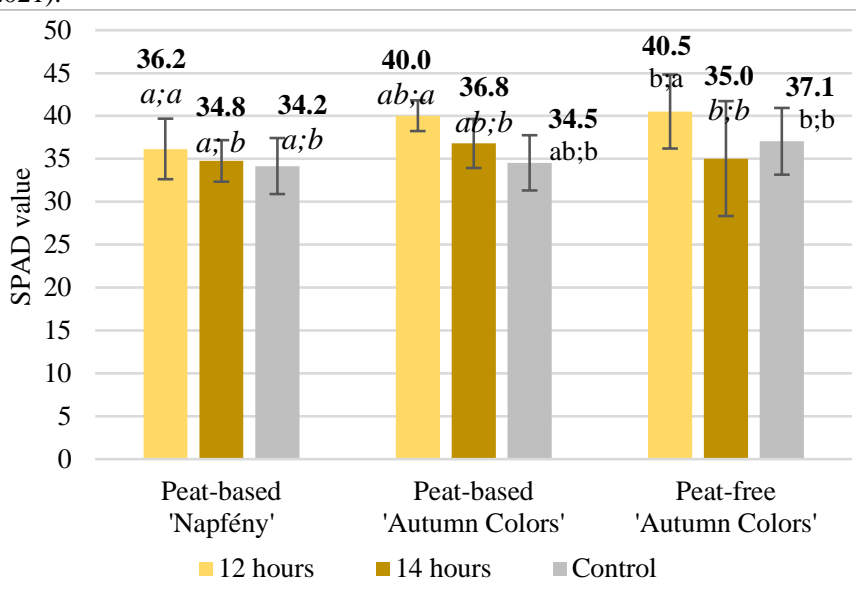

Notes: First different letters represent significant differences depending on media/varieties, second different letters represent significant differences depending on photoperiodic light treatments, which were determined with Tukey's test $(p=0.05)$. There is no interaction effect between lighting treatments and media.

Table 4. Relative chlorophyll content (SPAD value) of Rudbeckia hirta L. plantlets depending on photoperiodic lighting treatments and media (University of Debrecen, Biological Research and Plant Experiment Greenhouse Biodrome, Debrecen, Hungary, 2021).

\begin{tabular}{|c|c|c|c|c|}
\hline & $\begin{array}{l}14 \text { hours - } \\
\text { aeroponics }\end{array}$ & $\begin{array}{l}14 \text { hours - } \\
\text { perlite }\end{array}$ & $\begin{array}{l}12 \text { hours - } \\
\text { perlite }\end{array}$ & $\begin{array}{c}\text { Control - } \\
\text { perlite }\end{array}$ \\
\hline $\begin{array}{c}\text { 'Napfény' } \\
\text { (11 weeks) } \\
\pm S D\end{array}$ & $\begin{array}{c}32.9 a b \\
\pm 7.16 \\
\end{array}$ & $\begin{array}{c}30.9 a b \\
\pm 3.22 \\
\end{array}$ & $\begin{array}{r}35.3 b \\
\pm 6.64\end{array}$ & $\begin{array}{r}28.8 a \\
\pm 1.83\end{array}$ \\
\hline $\begin{array}{c}\text { 'Napfény' } \\
\text { (16 weeks) } \\
\pm S D\end{array}$ & $\begin{array}{l}\mathbf{4 0 . 1} b \\
\pm 1,95\end{array}$ & $\begin{array}{r}\mathbf{4 0 . 4} b \\
\pm 2.45\end{array}$ & $\begin{array}{l}46.8 c \\
\pm 1.56\end{array}$ & $\begin{array}{r}35.9 a \\
\pm 2.06\end{array}$ \\
\hline $\begin{array}{c}\text { 'Toto Gold' } \\
\text { (11 weeks) } \\
\pm S D \\
\end{array}$ & $\begin{array}{c}36.4 b c \\
\pm 1.3 \\
\end{array}$ & $\begin{array}{c}33.8 a b \\
\pm 1.2 \\
\end{array}$ & $\begin{array}{l}\mathbf{4 0 . 5} c \\
\pm 4.2 \\
\end{array}$ & $\begin{array}{c}31.6 a \\
\pm 1.9 \\
\end{array}$ \\
\hline $\begin{array}{c}\text { 'Autumn Colors' } \\
\text { (11 weeks) } \\
\pm S D\end{array}$ & $\begin{array}{c}34.7 a \\
\pm 2.8 \\
\end{array}$ & $\begin{array}{c}37.7 a b \\
\pm 4.9\end{array}$ & $\begin{array}{c}40.3 b \\
\pm 4.0 \\
\end{array}$ & $\begin{array}{c}34.3 a \\
\pm 3.3 \\
\end{array}$ \\
\hline $\begin{array}{c}\text { 'Prairie Sun' } \\
\text { (11 weeks) } \\
\pm S D\end{array}$ & $\begin{array}{c}39.9 b \\
\pm 3.2\end{array}$ & $\begin{array}{l}40.1 b \\
\pm 1.1\end{array}$ & $\begin{array}{l}\mathbf{4 0 . 8} b \\
\pm 3.6\end{array}$ & $\begin{array}{c}33.3 a \\
\pm 2.5\end{array}$ \\
\hline
\end{tabular}

Notes: Values followed by the different letters represent significant differences depending on treatments, which were determined with Tukey's test ( $p=0.05)$.

Different photosynthetic pigment content (chlorophyll a, chlorophyll b, chlorophyll a+b, carotenoids and xanthophyll/lutein - $\mathrm{mg} / \mathrm{g}$ ) of Rudbeckia varieties were evaluated depending on treatments in Table 5. In case of 'Toto Gold', different treatments (lighting and media) had no significant effect on each photosynthetic pigment content of the variety, except for the xanthophyll content of control plantlet, which was significantly lower, than other lighting treatments. 12 hours perlite lighting treatment of 16 weeks-old 'Napfény' resulted significantly higher chlorophyll $a$, chlorophyll $b$, chlorophyll $a+b$, carotenoids and xanthophyll (lutein) content (8.16, 3.39, 11.5, 3.58 and $2.19 \mathrm{mg} / \mathrm{g}$, consequently). Between the treatments, had no significant differences in any of the photosynthetic pigment content of 'Autumn Colors' In case of 'Prairie Sun', were obtained different results compared to 'Toto Gold', 'Napfény' or 'Autumn Colors' varieties. The content of chlorophyll $a$ of 14-hour aeroponics treatment was one of the highest among the varieties $(7.20 \mathrm{mg} / \mathrm{g})$. There was no significant difference between treatments of photosynthetic pigment and xanthophyll (lutein) content of 'Prairie Sun', but high photosynthetic pigment content of 14 hours aeroponics 'Prairie Sun' could have resulted by the rapidly growing of variety (Table 5).

Table 5. Photosynthetic pigment content (mg/g) of Rudbeckia hirta L. plantlets depending on photoperiodic lighting treatments and media (University of Debrecen, Biological Research and Plant Experiment Greenhouse - Biodrome, Debrecen, Hungary, 2021).

\begin{tabular}{|c|c|c|c|c|}
\hline $\begin{array}{l}\text { Photoperiodic } \\
\text { treatments }\end{array}$ & $\begin{array}{l}14 \text { hours - } \\
\text { aeroponics }\end{array}$ & $\begin{array}{l}14 \text { hours - } \\
\text { perlite }\end{array}$ & $\begin{array}{l}12 \text { hours - } \\
\text { perlite }\end{array}$ & $\begin{array}{l}\text { Control - } \\
\text { perlite }\end{array}$ \\
\hline & \multicolumn{4}{|c|}{ Chl a $(\mathrm{mg} / \mathrm{g})$} \\
\hline $\begin{array}{c}\text { 'Toto Gold' } \\
\pm S D \text { (11 weeks) }\end{array}$ & $\begin{array}{l}7.05 a \\
\pm 0.693\end{array}$ & $\begin{array}{r}\mathbf{6 . 0 2} a \\
\pm 0.983\end{array}$ & $\begin{array}{l}7.15 a \\
\pm 1.143\end{array}$ & $\begin{array}{r}\mathbf{6 . 0 1} a \\
\pm 1.121\end{array}$ \\
\hline $\begin{array}{c}\text { 'Napfény' } \\
\pm S D \text { (16 weeks) }\end{array}$ & $\begin{array}{l}6.40 a \\
\pm 1.141\end{array}$ & $\begin{array}{l}5.58 a \\
\pm 0.714\end{array}$ & $\begin{array}{l}\mathbf{8 . 1 6} b \\
\pm 0.305\end{array}$ & $\begin{array}{l}\mathbf{6 . 1 5} a \\
\pm 0.769\end{array}$ \\
\hline $\begin{array}{c}\text { 'Prairie Sun' } \\
\pm S D \text { (11 weeks) }\end{array}$ & $\begin{array}{l}7.03 a \\
\pm 0.379\end{array}$ & $\begin{array}{c}5.27 b c \\
\pm 1.02\end{array}$ & $\begin{array}{l}6.79 a b \\
\pm 0.513\end{array}$ & $\begin{array}{l}5.14 c \\
\pm 0.996\end{array}$ \\
\hline \multirow[t]{2}{*}{$\begin{array}{l}\text { 'Autumn Colors' } \\
\pm S D \text { (11 weeks) }\end{array}$} & $\begin{array}{r}6.25 a \\
\pm 0.697 \\
\end{array}$ & $\begin{array}{l}\mathbf{5 . 4 1} a \\
\pm 1.136 \\
\end{array}$ & $\begin{array}{r}6.79 a \\
\pm 1.020 \\
\end{array}$ & $\begin{array}{r}6.78 a \\
\pm 1.281 \\
\end{array}$ \\
\hline & \multicolumn{4}{|c|}{$C h l b(\mathrm{mg} / \mathrm{g})$} \\
\hline $\begin{array}{c}\text { 'Toto Gold' } \\
\pm S D \text { (11 weeks) }\end{array}$ & $\begin{array}{l}3.08 a \\
\pm 0.385\end{array}$ & $\begin{array}{l}2,40 a \\
\pm 0.433\end{array}$ & $\begin{array}{l}2.77 a \\
\pm 0.509\end{array}$ & $\begin{array}{l}2.28 a \\
\pm 0.457\end{array}$ \\
\hline $\begin{array}{c}\text { 'Napfény' } \\
\pm S D \text { (16 weeks) }\end{array}$ & $\begin{array}{l}2.62 a \\
\pm 0.406\end{array}$ & $\begin{array}{l}2.24 a \\
\pm 0.388\end{array}$ & $\begin{array}{l}3.39 b \\
\pm 0.166\end{array}$ & $\begin{array}{l}2.36 a \\
\pm 0.289\end{array}$ \\
\hline $\begin{array}{c}\text { 'Prairie Sun' } \\
\pm S D \text { (11 weeks) }\end{array}$ & $\begin{array}{l}2.80 a \\
\pm 0.163 \\
\end{array}$ & $\begin{array}{l}2.11 a b \\
\pm 0.406\end{array}$ & $\begin{array}{l}2.71 a b \\
\pm 0.235\end{array}$ & $\begin{array}{l}2.04 b \\
\pm 0.432\end{array}$ \\
\hline \multirow[t]{2}{*}{$\begin{array}{l}\text { 'Autumn Colors' } \\
\pm S D \text { (11 weeks) }\end{array}$} & $\begin{array}{l}2.70 a \\
\pm 0.370 \\
\end{array}$ & $\begin{array}{l}2.15 a \\
\pm 0.487 \\
\end{array}$ & $\begin{array}{l}2.68 a \\
\pm 0.415 \\
\end{array}$ & $\begin{array}{l}2.52 a \\
\pm 0.428 \\
\end{array}$ \\
\hline & \multicolumn{4}{|c|}{$C h l a+b(m g / g)$} \\
\hline $\begin{array}{c}\text { 'Toto Gold' } \\
\pm S D \text { (11 weeks) }\end{array}$ & $\begin{array}{l}\mathbf{1 0 . 1 4 a} \\
\pm 1.075\end{array}$ & $\begin{array}{l}8.43 a \\
\pm 1.146 \\
\end{array}$ & $\begin{array}{l}9.93 a \\
\pm 1.650\end{array}$ & $\begin{array}{l}\mathbf{8 . 3 0} a \\
\pm 1.577\end{array}$ \\
\hline $\begin{array}{c}\text { 'Napfény' } \\
\pm S D \text { (16 weeks) }\end{array}$ & $\begin{array}{l}\mathbf{9 . 0 3 a} \\
\pm 1.540 \\
\end{array}$ & $\begin{array}{l}7.82 a \\
\pm 1.101 \\
\end{array}$ & $\begin{array}{l}11.55 b \\
\pm 0.468\end{array}$ & $\begin{array}{l}8.52 a \\
\pm 0.058 \\
\end{array}$ \\
\hline $\begin{array}{c}\text { 'Prairie Sun' } \\
\pm S D \text { (11 weeks) }\end{array}$ & $\begin{array}{l}\mathbf{9 . 8 4} a \\
\pm 0.527 \\
\end{array}$ & $\begin{array}{l}7.38 b c \\
\pm 1.424\end{array}$ & $\begin{array}{l}9.51 a b \\
\pm 0.747 \\
\end{array}$ & $\begin{array}{l}7.18 \mathrm{C} \\
\pm 1.427 \\
\end{array}$ \\
\hline $\begin{array}{l}\text { 'Autumn Colors' } \\
\pm S D \text { (11 weeks) } \\
\end{array}$ & $\begin{array}{r}8.95 a \\
\pm 1.064 \\
\end{array}$ & $\begin{array}{r}7.56 a \\
\pm 1.623 \\
\end{array}$ & $\begin{array}{r}9.47 a \\
\pm 1.702 \\
\end{array}$ & $\begin{array}{r}9.30 a \\
\pm 1.702 \\
\end{array}$ \\
\hline & \multicolumn{4}{|c|}{$\operatorname{Car}(\mathrm{mg} / \mathrm{g})$} \\
\hline $\begin{array}{c}\text { 'Toto Gold' } \\
\pm S D \text { (11 weeks) }\end{array}$ & $\begin{array}{l}3,17 a \\
\pm 0.204\end{array}$ & $\begin{array}{l}2.62 a \\
\pm 0.361\end{array}$ & $\begin{array}{l}3.12 a \\
\pm 0.486\end{array}$ & $\begin{array}{l}2.50 a \\
\pm 0.475\end{array}$ \\
\hline $\begin{array}{c}\text { 'Napfény' } \\
\pm S D \text { (16 weeks) }\end{array}$ & $\begin{array}{l}2.85 a \\
\pm 0.444\end{array}$ & $\begin{array}{l}2.51 a \\
\pm 0.348\end{array}$ & $\begin{array}{l}3.58 b \\
\pm 0.140\end{array}$ & $\begin{array}{l}2.64 a \\
\pm 0.315\end{array}$ \\
\hline $\begin{array}{c}\text { 'Prairie Sun' } \\
\pm S D \text { (11 weeks) }\end{array}$ & $\begin{array}{l}3.08 a \\
\pm 0.090\end{array}$ & $\begin{array}{l}2.34 b c \\
\pm 0.391\end{array}$ & $\begin{array}{l}2.90 a b \\
\pm 0.224\end{array}$ & $\begin{array}{l}2.23 c \\
\pm 0.434\end{array}$ \\
\hline \multirow[t]{2}{*}{$\begin{array}{l}\text { 'Autumn Colors' } \\
\pm S D \text { (11 weeks) }\end{array}$} & $\begin{array}{r}2.71 a \\
\pm 0.297 \\
\end{array}$ & $\begin{array}{l}\mathbf{2 , 0 9} a \\
\pm 0.242 \\
\end{array}$ & $\begin{array}{r}2.88 a \\
\pm 0.418 \\
\end{array}$ & $\begin{array}{r}2.58 a \\
\pm 0.614 \\
\end{array}$ \\
\hline & \multicolumn{4}{|c|}{ Xant - Iutein $(\mathrm{mg} / \mathrm{g})$} \\
\hline $\begin{array}{c}\text { 'Toto Gold' } \\
\pm S D \text { (11 weeks) }\end{array}$ & $\begin{array}{r}1.68 a \\
\pm 0.144 \\
\end{array}$ & $\begin{array}{r}1.59 a \\
\pm 0.268 \\
\end{array}$ & $\begin{array}{r}1.79 a \\
\pm 0.273 \\
\end{array}$ & $\begin{array}{c}\mathbf{1 . 0 8 b} \\
\pm 0.226 \\
\end{array}$ \\
\hline $\begin{array}{c}\text { 'Napfény' } \\
\pm S D \text { (16 weeks) }\end{array}$ & $\begin{array}{r}1.61 a \\
\pm 0.273 \\
\end{array}$ & $\begin{array}{r}1.53 a \\
\pm 0.280 \\
\end{array}$ & $\begin{array}{l}2.19 b \\
\pm 0.091 \\
\end{array}$ & $\begin{array}{r}1.63 a \\
\pm 0.199 \\
\end{array}$ \\
\hline $\begin{array}{c}\text { 'Prairie Sun' } \\
\pm S D \text { (11 weeks) }\end{array}$ & $\begin{array}{r}1.56 a \\
\pm 0.028 \\
\end{array}$ & $\begin{array}{r}1.41 a \\
\pm 0.256 \\
\end{array}$ & $\begin{array}{r}1.59 a \\
\pm 0.134 \\
\end{array}$ & $\begin{array}{l}1.32 a \\
\pm 0.305 \\
\end{array}$ \\
\hline $\begin{array}{l}\text { 'Autumn Colors' } \\
\pm S D \text { (11 weeks) }\end{array}$ & $\begin{array}{r}1.40 a \\
\pm 0.172\end{array}$ & $\begin{array}{r}1,20 a \\
\pm 0.262\end{array}$ & $\begin{array}{r}1.64 a \\
\pm 0.249\end{array}$ & $\begin{array}{r}1.48 a \\
\pm 0.266\end{array}$ \\
\hline
\end{tabular}

Notes: Values followed by the different letters represent significant differences depending on treatments, which were determined with Tukey's test ( $p=0.05)$. 


\section{Discussion}

Based on the results of the soilless seedling cultivation experiments and literature data (Luczkiewcz \& Cisowski, 2001; Almeida-Cortez et al., 2003; Elkins \& van Iersel, 2020), the investigated Rudbeckia hirta varieties ('Napfény', 'Toto Gold', 'Autumn Colors' and 'Prairie Sun') are suitable both in the aeroponics system (GHE Rainforest72) and in 100\% perlite for growing with the adequate nutrient solutions. The soil-free, hydroponic cultivation of Rudbeckia may be contributed to utilize widely as indoor and outdoor flowering plants, even in controlled or vertical cultivation systems, or in facilities (e.g. hospitals) where terrestrial media are prohibited (Salas et al. 2010). In addition, due to various ingredients of the plant: polysaccharides, flavonoids, phenolic acids, anthocyanin compounds, polyacetylene derivatives, etc. (Michael et al., 2014; Palmer et al., 2019) could utilize as medicinal purposes. These compounds are obtained primarily on the roots, therefore hydroponic cultivation systems and media can facilitate easier extractions (reducing contaminants and root loss). With the adequate nutrient solution and light treatments, even the amount of these secondary metabolites and various compounds could be influenced (Almeida-Cortez, 2003; Moldovan et al., 2017).

Morphological properties were determined basically kind of varieties, in our experiments photoperiodic lighting treatments and media also affected habitats and the development of plantlets. Different habitats of plantlets were confirmed the photoperiodic sensitivity of investigated Rudbeckia varieties. Each variety was grown under 12 hours light conditions (short daylight) did not initiate flowers, remained in stage of leaf rosette. In case of 14 hours or control (natural short day with 14 hours light pollution) plantlets were developed inflorescences and/or flower buds. Inflorescence axis of varieties were produced from 8 weeks. 11 weeks-old plantlets were suitable for acclimatization or planting in case of aeroponics or perlite media treatments. Foreign and domestic descriptions of Rudbeckia varieties (Benary, 2013, 2020; NARIC, 2020a,b) included that growing time of Rudbeckia hirta is at least 12 weeks, but in (early) spring, potted or annual flowerbed Rudbeckia plantlets mostly do not have flower buds in Hungarian conditions. 14 hours of long-day treatment can be shortened the cultivation time of plantlets by up to 3-4 weeks (depending on the variety and other production conditions). However, the utilization of LEDs or HPS fixtures increases the production costs, but light manipulation as a growth regulation tool is resulted to produce preferable quality products and minimize crop times. Depending on the light treatment, more branching, compact plantlets can be produced with more leaves, the number of shoots and flower buds with higher chlorophyll content.

Our experiments with peat-free media with Rudbeckia varieties resulted that seedling cultivation in peat-free soil media without peat can be also possible and effective (peat-free 'Autumn Colors' resulted in more shoots and leaves). Large scale utilization of peat-free growing media, even based on domestic fibre sources (urban and other green waste, various biomass crops, etc.), would provide a shift towards sustainability and circular farming, which could also reduce GHG emissions and also help to protect and preserve peatland ecosystems. It would be suggested to continue our lighting and media experiments with other Rudbeckia varieties and other ornamental plants.

\section{Acknowledgements}

The publication is supported by the EFOP-3.6.1-16-201600022 project. The project is co-financed by the European Union and the European Social Fund.

This study based on the part of the thesis of K. Koncz, 2021, supervisor: G. Antal. We thank Dr. Szilvia Kisvarga and Dr. László Orlóci (National Agricultural Research and Innovation Centre - NARIC, Hungary) for providing Rudbeckia hirta seeds.

\section{References}

Almeida-Cortez, J., Shipley, B., Arnason, J. T. (2003): Effects of nutrient availability on the production of pentaynene, a secondary compound related to defense, in Rudbeckia hirta. Plant Species Biology, 18. 85-89., https://doi.org/10.1111/j. 1442-1984.2003.00095.X

Beckwith, D. D. (1991): Characterization of juvenility and photoperiodic responses of Rudbeckia hirta originating from different latitudes, Master of Science Thesis, Blacksburg, Virginia, USA. 87 p., https://vtechworks.lib.vt.edu/handle/ 10919/45987

Bek, D., Lennartsson-Turner. M., Lanari, N., Conroy, J., Evans, A. (2020): Transitioning to peat free horticulture in the UK: an assessment of policy, progress, opportunities and barriers. https://hta.org.uk/uploads/assets/219d3ce6-e9a2-4659b0a52d7a1bd6dd1e/ FINALCOVNTRYUNIREPORTHTAGMAFinalCoversauthors29Sept20-1.pdf, 96 p.

Benary (2013): Rudbeckia. Benary's Award Winning Program. https://www.benary.de/sites/default/files/uploads/ 130211_Rudbeckia-Study_Letter_A.pdf

Benary (2020): Rudbeckia hirta 'Toto Gold', 'Autumn Colors', 'Prairie Sun', 'Goldilocks': https://www.benary.com/ en/product/U9040

Blanchard, M. G., Runkle, E. S. (2010): Intermittent light from a rotating high-pressure sodium lamp promotes flowering of long-day plants. HortScience, 45(2): 236-241. https://doi.org/10.21273/HORTSCI.45.2.236

Brakie, M. (2019): Plant Guide for black-eyed Susan (Rudbeckia hirta). USDA-Natural Resources Conservation Service, East Texas Plant Materials Center. Nacogdoches, TX., https://www.nrcs.usda.gov/Internet/FSE_PLANTMATERIAL S/publications/etpmcpg13467.pdf

Duma, M., Alsina, I., Zeipina, S., Lepse, L., Dubova, L. (2014): Leaf vegetables as source of phytochemicals. In 9th Baltic Conference on Food Science and Technology "Food for Consumer Well-Being” FOODBALT 2014 Conference Proceedings. Jelgava, LLU. P, 262-265.

Elkins, C., van Iersel, M. W. (2020): Longer photoperiods with the same daily light integral improve growth of Rudbeckia seedlings in a greenhouse. HortScience, 55(10): 1676-1682. https://doi.org/10.21273/HORTSCI15200-20

European Commission (2018): 52 steps - towards a greener city. Luxembourg: Publications Office of the European Union, Directorate-General for Environment, https:/op.europa.eu/ en/publication-detail/-/publication/080dffa8-49c5-11e8-be1d01aa75ed71a1/language-hu/format-PDF 
FAO (2014): Towards climate-responsible peatlands management, Mitigation of climate change in Agriculture Series 9. Biancalani, R., Avagyan A. (eds.). Food and Agiculture Organization of the United Nations (FAO). http://www.fao.org/3/i4029e/i4029e.pdf

GHE (2021): Flora Series, General Hydroponics, https://www.plantplanet.de/mediafiles/Sonstiges/GHE/Terra\%2 0Aquatica\%20-\%20GHE\%20 -\%20TriPart\%20Anleitung.pdf

Hambäck, P. A. (2001): Direct and indirect effects of herbivory: feeding by spittlebugs affects pollinator visitation rates and seedset of Rudbeckia hirta. Ecoscience, 8(1): 45-50. https://doi.org/10.1080/11956860.2001.11682629

Harkess, R. L., Lyons, R. E. (1994): Rudbeckia hirta L.: A versatile North American wildflower. HortScience, 29(3): 134227. https://doi.org/10.21273/HORTSCI.29.3.134

IUCN (2018): UK Peatland Strategy 2018-2040. International Union for the Conservation of Nature (IUCN). https://www.iucn-uk-peatlandprogramme.org/sites/www.iucnuk-eatlandprogramme.org/files/2018_UK\%20Peatland\%20 Strategy_DIGITAL.pdf

Kozai, T. (2016): Why LED Lighting for Urban Agriculture?. In: Kozai T., Fujiwara K., Runkle E. (eds) LED Lighting for Urban Agriculture. Springer, Singapore. https://doi.org/10.1007/978-981-10-1848-0_1

Luczkiewcz, M., Cisowski, W. (2001): Optimisation of the second phase of a two phase growth system for anthocyanin accumulation in callus cultures of Rudbeckia hirta. Plant Cell, Tissue and Organ Culture, 65. 57-68, https://doi.org/10.1023/ A:1010652507981

Michael, B. R., Gedara, S. R., Amer, M. M., Stevenson, L., Ahmed, A. F. (2014): Evidence-based medicinal value of Rudbeckia hirta L. flowers. Natural Product Research, 28(12): 909-913. https://doi.org/10.1080/14786419.2014.891202

Moldovan, Z., Buleandră, M., Oprea, E., Mînea, Z. (2017): Studies on chemical composition and antioxidant activity of Rudbeckia triloba. Journal of Analytical Methods in
Chemistry, Vol. 2017, Article ID 3407312, 8 pages, https://doi.org/10.1155/2017/3407312

Murneek, A. E. (1940): Length of day and temperature effects in Rudbeckia, Botanical Gazette, 102. 269-279. www.journals.uchicago.edu by Columbia University

NARIC (2020a): In memoriam Dr. Kováts Zoltán, https://fruitresearch.naik.hu/gyki-in-memoriam-dr-kovatszoltan

NARIC (2020b): Rudbeckia hirta, https://fruitresearch. naik.hu/gyki-katalogus-rudbeckia-hirta-kupvirag

Palmer, I. E., Ranney, T. G., Lynch, N. P., Bir, R. E. (2009): Crossability, cytogenetics, and reproductive pathways in Rudbeckia subgenus Rudbeckia. HortScience, 44(1): 44-48. https://doi.org/10.21273/HORTSCI.44.1.44

Roberto, L., Runkle, E. S. (2017): Light management in controlled environments. Meister Media Worldwide, First Edition, ISBN-10: 1544254490, 11-54.

Runkle, E. S., Heins, R. D., Cameron, A. C., Carlson, W. H. (1999): Photoperiod and cold treatment regulate flowering of Rudbeckia fulgida 'Goldsturm'. HortScience, 34(1): 55-58. https://doi.org/10.21273/ HORTSCI.34.1.55

Salas, M. C., Verdejo, M. M., Sánchez, A., Guzmán, M., Valenzuela, J. L., Montero, J. L. (2010): Vertical gardening. Adaptation of hydroponic systems and ornamental species. In XXVIII International Horticultural Congress on Science and Horticulture for People (IHC2010): International Symposium on 937. 1153-1160.

Sardare, M D., Shraddha V. A. (2013): A review on plant without soil-hydroponics. International Journal of Research in Engineering and Technology 2(3): 299-304. ISSN: 2319-1163

Werner, J., Okada, Y., Karlsson, M. (2009): Using light emitting diodes in high latitude greenhouse production. In VI International Symposium on Light in Horticulture 907, 287290. https://doi.org/10.17660/ActaHortic.2011.907.46 